\title{
Survey of Macrofungi (including Truffes) in Qatar
}

\author{
Roda F. Al-Thani
}

\author{
Department of Biological and Environmental Sciences, College of Arts and Sciences, Qatar \\ University, Qatar
}

Received: February 16, 2010 / Accepted: May 27, 2010

\begin{abstract}
Fourteen macrofungal genera belonging to 11 families and 7 orders were identified. These were isolated from different habitats (semi- desert, gardens, park, decayed roots of dead trees and under trees) in Qatar. Macrofungi are defined here as ascomycetes and basidiomycetes with large, conspicuous spore-bearing structures that form above or beneath ground. This study indicated that the distribution of macrofungi is dependent on the plant community and the environmental conditions.
\end{abstract}

Key words: Macrofungi, desert truffles, biodiversity, Qatar.

\section{Introduction}

Qatar is a limestone peninsula predictive northward into the Arabian Gulf. It is approximately $160 \mathrm{~km}$ long by $80 \mathrm{~km}$ wide, consisting mostly of low-lying, arid, stony desert. Average temperatures vary between $12^{\circ} \mathrm{C}-21{ }^{\circ} \mathrm{C}$ in January, and $35^{\circ} \mathrm{C}$ - $49^{\circ} \mathrm{C}$ from June to September. The climate during autumn and spring is moderate, while winter can be surprisingly cool. Average rainfall is $5-9 \mathrm{~cm}$ per year, although the actual amount varies considerably from one year to the next.

Macrofungi are fungi that form large fruiting bodies visible without the aid of a microscope. The distribution of macrofungal species is low in hot and dry seasons while they are abundant in spring and autumn due to the humid climate as well as the richness of the flora at this time (Sibounnavong et al., 2008).

Macrofungal studies have long been of interest to scientists in Qatar and elsewhere as well as the community due to their significant roles in human life, their use in the pharmaceutical industry, and the mass production of cultivated fungi in the food industry (Lindequist et al., 2005), as well as their vital role in biodegradation (de Boer et al., 2005).

\footnotetext{
* Corresponding author: ralthani@qu.edu.qa
}

Some of the different species of desert truffle that grow in arid and semi arid areas and that prefer high $\mathrm{pH}$ calcareous soils have been found in Qatar. Traditionally, desert truffles are used by some people for food, as a cash crop, and as medicine for a variety of ailments (Mandeel and Al-Laith, 2007).

Surveys of macrofungi were reported by different researchers but little information is reported about the macrofungi of Qatar (Moubasher, 1993). The aim of this study was to determine and provide more data on the hyper off macrofungi and desert truffle species in the harsh environment of Qatar.

\section{Materials and Methods}

Visually conspicuous macrofungal species were collected from different natural sites (natural areas, damp places of public gardens, on decayed roots of the dead trees and under trees), photographed and kept for laboratory identification.

Materials were examined and morphological characteristics were recorded and identified to species level by comparison to literatures (Moustafa, 1995; Segedin and Pennycook, 2001; 

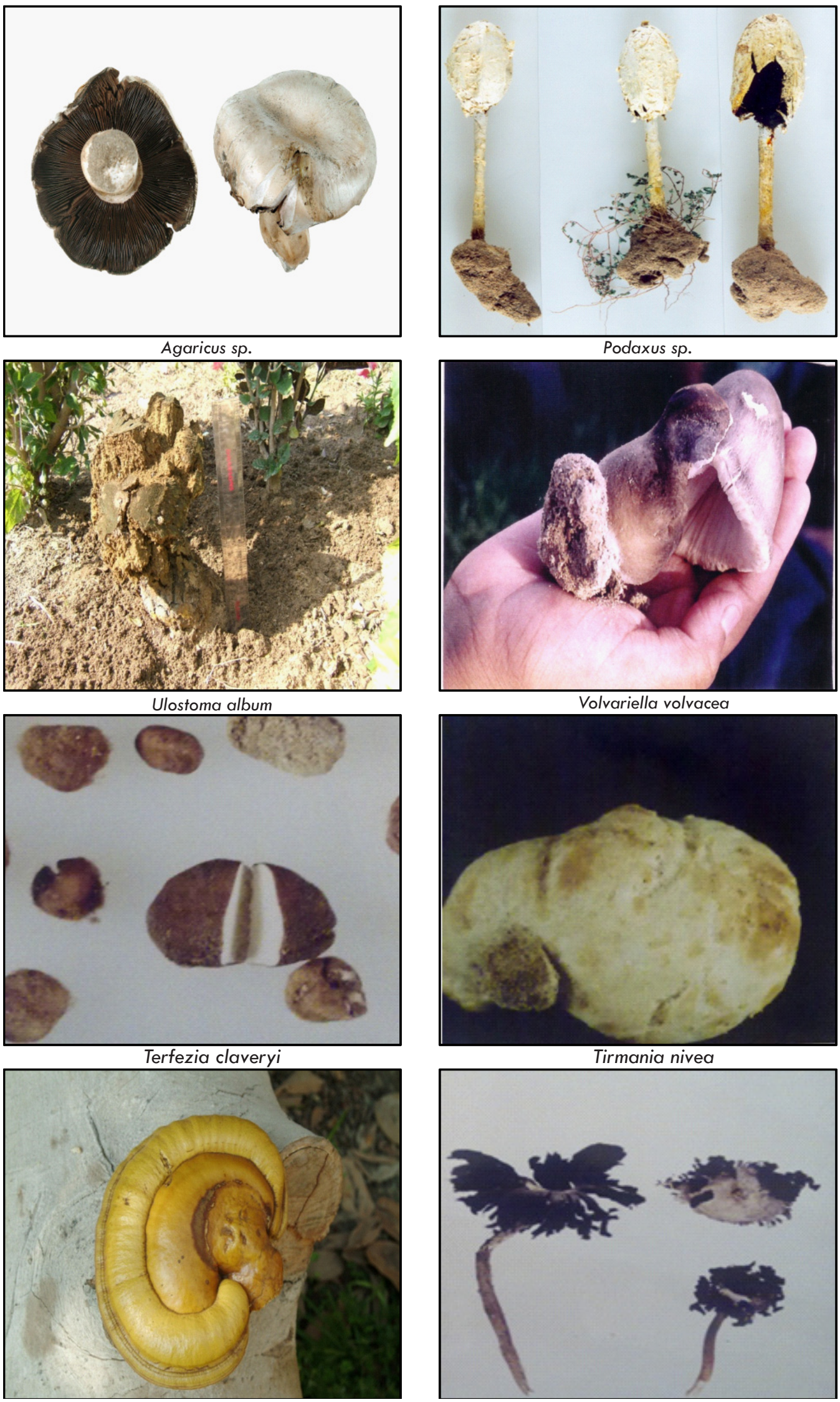

Ganoderma lucidum

Montagnea arenaria

Figure 1. Some macrofungi and Truffle species reported for Qatar. 


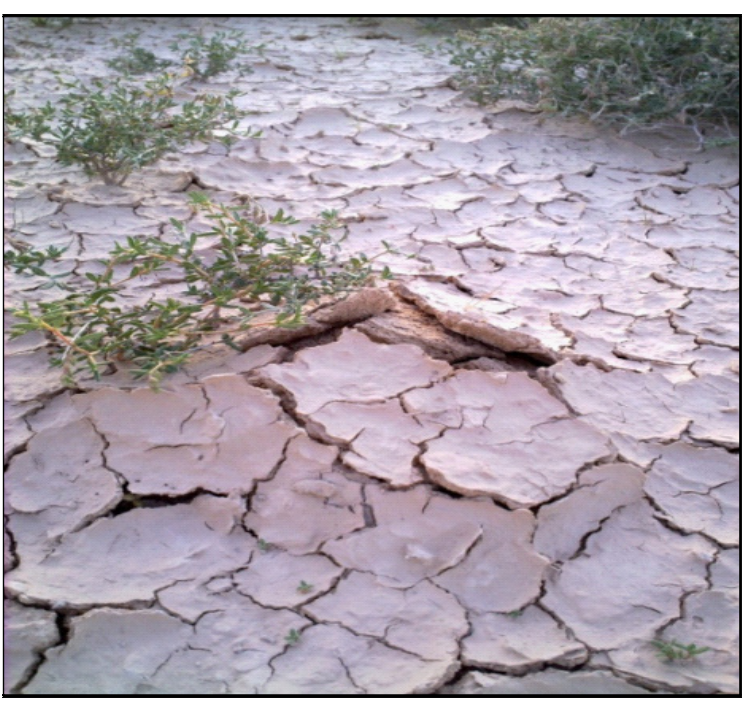

Figure 2. Tirmania nivea "Zubaidi" form mycorrhizas on roots of Helianthemum sp.

Jean Lodge et al., 2004; Abou-Zeid and Altalhi, 2006; Helfer, 2008).

\section{Results and Discussion}

In this study, 14 macrofungal genera belonging to 11 families and 7 orders were identified. The data presented in Table 1 and Plate 1, document the identified macrofungi .

Two genera of the family Terfeziaceae occur in Qatar. These are Terfezia and Tirmania. Terfezia spp. have spherical and ornamented spores, while Tirmania spp. have smooth spores and amyloid asci. The fruitbodies are round, tan to brown, and look like small, sandy potatoes. The three well known varieties of truffles, namely, Phaeangium lefebvrei (Hoper) (Pyronemataceae), Terfezia claveryi (Khlasi) (Terfeziaceae), and Tirmania nivea (Zabidi) (Pezizaceae) are common in the Qatar desert (Table 1).

There is rising interest in mapping the macrofungal flora of many areas to obtain distribution records similar to those already existing for flowering plants (Mueller et al., 2007). However, unlike plants, the identification of macrofungi relies on the collection of fruiting bodies, which in turn is largely dependent upon the availability of moisture, that is, in most cases, seasonal rains (Arora, 1991). Hayes (1976) reported that natural geographic areas of mushrooms extend all over the northern Hemisphere outside the tropic and the arctic. Gray (1997) reported that Agaricus campastris is common wild mushrooms in Europe and America. Abou-Zeid and Altalhi (2006) recorded that the highest frequency occurrence of wild mushrooms in Al-Taif Governorate in Saudi Arabia was for Agaricus bisporus; Lepiota procera and L. rhacodes.

Al-Fatimi et al. (2006) on an ethnobotanical study on fungi in Yemeni ethnomedicine found that the fungus Podaxis pistillaris (Podaxales, Podaxaceae, Basidiomycetes) exhibits antibacterial activity against Staphylococcus aureus, Micrococcus flavus, Bacil- lus subtilis, Proteus mirabilis, Serratia marcescens and Escherichia coli. In China, mushrooms can be used to solve several problems such as human nutrition and avoiding waste pollution by degrading waste products of animals (Chen Li and Nicholas, 2005). Chang and Lee (2004) observed that species of local macrofungi are utilized not only for food, but also as medicine and for spiritual purposes, including discouraging certain undesirable behavior in children.

Genera Terfezia and Tirmania in the family Terfeziaceae, order Pezizales, grow in arid and semi-arid areas of the Mediterranean region, the Arabian Peninsula, and North-Africa. Some have been found in South Africa and China. Species of Terfezia and Tirmania prefer high $\mathrm{pH}$ calcareous soils, typical of desert soils. Although the genera Terfezia and Tirmania are primarily ectomycorrhizal (forming a sheath around the roots of their host plant), they are highly adaptable (Diez et al., 2002). Some species, like Terfezia arenaria, Terfezia claveryi, and Tirmania pinoyi, form endomycorrhizal associations in phosphate-poor soils and ectomycorrhizal associations in phosphate-rich soils. Species of both genera form mycorrhizas on roots mainly of members of the genus Helianthemum (family Cistaceae) (see Fig. 1).

Heavy rains, thunder and soil type are the most important reasons in truffle formation. The role of desert truffles on traditional, socioeconomic, ecology and socio-cultural in Qatar and others Gulf States is well known. In Qatar two Truffle species were identified; Tirmania nivea "Zubaidi" was found to be the most preferred expensive and common type of truffle in the region due to its pleasant light smell, delicacy, and soft white tissues. This was followed by Terfezia claveryi "Ikhlasi".

The lists of macrofungi in this paper provide the baseline data needed for ongoing assessment of changes in biological diversity in Qatar. It is an important first step towards a "checklist of macrofungi in Qatar" and a source of baseline data for the scientific community.

\section{Acknowledgments}

I wish to thank Prof. Eklas Abd Elbary for her expert advice in this studies and Prof. Malcolm Potts for his helpful comments on the manuscript.

\section{References}

Abou-Zeid AM and Altalhi AE (2006) Survey of Some Mushrooms in Al-Taif Governorate of Saudi Arabia. World Journal of Agricultural Sciences 2 (1): 01-05.

Al-Fatimi M, Ju lich WD, Jansen $R$ and Lindequist $U$ (2006) Bioactive Components of the Traditionally used Mushroom Podaxis pistillaris. eCAM 3(1): 87-92.

Arora D (1991) All that the Rain Promises and More. A Hip Pocket Guide to Western Mushroom. Ten Speed Press, 261 pp.

Chang YS and Lee SS (2004) Utilization of macrofungi species in Malaysia. Fungal Diversity 15: 15-22.

Chen Li and Nicholas HO (2005) The most widely recognized mushroom: Chemistry of the genus Amanita. Life Science 78:532-538.

De Boer W, Folman LB, Summerbell RC and Boddy L (2005) Living in a fungal world: impact of fungi on soil bacterial niche development. FEMS Microbiology Review 29: 795-811. 
Diez J, Manjon JL and Martin F (2002) Molecular phylogeny of the mycorrhizal desert truffles (Terfezia and Tirmania), host specificity and edaphic tolerance. Mycologia 94 (2): 247-259.

Gray W (1997) The use of fungi as food processing. CRC Press, New York, USA., pp: 30.

Hayes WA (1976) New looks at mushrooms. J Nutrition and Food Sciences, 42: 2-6.

Helfer S (2008) Mycota of South-West Asia. Turkey Journal of Botany. 32: $481-484$

Jean Lodge D J, Ammirati JF, O'Dell TE and Mueller GM (2004) Collecting and Describing Macrofungi. In: $G$ Mueller, $G$ Bills and $M$ Foster (eds) Biodiversity of Fungi inventory and monitoring methods. Elsevier Academic Press, pp. 128-158.

Lindequist U, Niedermeyer THJ and Ju“lich WD (2005) The pharmacological potential of mushrooms. eCAM 2: 285-299.

Mandeel Q A and Al-Laith A A (2007) Ethnomycological aspects of the desert truffle among native Bahraini and non-Bahraini peoples of the Kingdom of Bahrain. Journal of Ethnopharmacology. 110 (1): $118-129$.

Moubasher AH (1993) Soil Fungi in Qatar and other Arab Countries, University of Qatar Press, Doha, Qatar, pp. 566.

Moustafa AF (1995) Taxonomic studies on the fungi of Kuwait. Ill. Ascomycotina (plectomycetes and discomycetes). Journal of University of Kuwait 12: 79-100.

Mueller GM. et al. (2007) Global diversity and distribution of macrofungi. Biodiversity and Conservation. 16: 37-48

Segedin BP and Pennycook SR (2001) A nomenclatural checklist of agarics, boletes and related secotioid and gasteromcetous fungi recorded from New Zealand. New Zealand Journal of Botany 39: 285-348

Sibounnavong P, Cynthia CD, Kalaw SP, Reyes RG and Soytong K (2008) Some species of macrofungi at Puncan, Carranglan, Nueva Ecija in the Philippines. Journal of Agricultural Technology 4 (2): 105-115. 